\title{
A magnetic biocatalyst based on mussel-inspired polydopamine and its acylation of dihydromyricetin
}

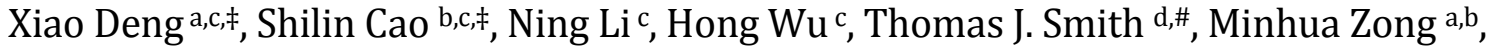 \\ Wenyong Lou a,c,* \\ a State Key Laboratory of Pulp and Paper Engineering, South China University of Technology, Guangzhou 510640, Guangdong, China \\ b School of Chemistry and Chemical Engineering, South China University of Technology, Guangzhou 510640, Guangdong, China \\ c Laboratory of Applied Biocatalysis, School of Food Science and Technology, South China University of Technology, Guangzhou 510640, Guangdong, China \\ d Biomolecular Sciences Research Centre, Sheffield Hallam University, Sheffield, S1 1WB, UK
}

A R T I C L E I N F O

Article history:

Received 1 November 2015

Accepted 4 January 2016

Published 5 April 2016

\section{Keywords:}

Magnetic iron oxide

Nanoparticle

Polydopamine

Aspergillus niger lipase

Dihydromyricetin

Acylation

\begin{abstract}
A B S T R A C T
A support made of mussel-inspired polydopamine-coated magnetic iron oxide nanoparticles (PD-MNPs) was prepared and characterized. The widely used Aspergillus niger lipase (ANL) was immobilized on the PD-MNPs (ANL@PD-MNPs) with a protein loading of $138 \mathrm{mg} / \mathrm{g}$ and an activity recovery of $83.6 \%$ under optimized conditions. For the immobilization, the $\mathrm{pH}$ and immobilization time were investigated. The $\mathrm{pH}$ and thermal and storage stability of the ANL@PD-MNPs significantly surpassed those of free ANL. The ANL@PD-MNPs had better solvent tolerance than free ANL. The secondary structure of free ANL and ANL@PD-MNPs was analyzed by infrared spectroscopy. A kinetic study demonstrated that the ANL@PD-MNPs had enhanced enzyme-substrate affinity and high catalytic efficiency. The ANL@PD-MNPs was applied as a biocatalyst for the regioselective acylation of dihydromyricetin (DMY) in DMSO and gave a conversion of 79.3\%, which was higher than that of previous reports. The ANL@PD-MNPs retained over 55\% of its initial activity after 10 cycles of reuse. The ANL@PD-MNPs were readily separated from the reaction system by a magnet. The PD-MNPs is an excellent support for ANL and the resulting ANL@PD-MNPs displayed good potential for the efficient synthesis of dihydromyricetin-3-acetate by enzymatic regioselective acylation.
\end{abstract}

(c) 2016, Dalian Institute of Chemical Physics, Chinese Academy of Sciences. Published by Elsevier B.V. All rights reserved.

\section{Introduction}

The biological catalyst lipase (glycerol ester hydrolases E.C. 3.1.1.3) is widely used in the production of biofuels, organic synthetic compounds, detergents, perfumes, cosmetics, leather, enantiopure pharmaceuticals, medical diagnostics, food and feeds [1,2]. Aspergillus niger lipase is a well known biocatalyst because of its wide application in the chemoselective, enantioselective and regioselective hydrolysis and synthesis of a broad range of non-natural esters [3]. However, the disadvantages of the free lipase such as poor mechanical stability, non-recyclability and difficulty in separating it from the prod-

\footnotetext{
* Corresponding author. Tel/Fax: +86-20-22236669; E-mail: wylou@scut.edu.cn

\# Corresponding author. E-mail: t.j.smith@shu.ac.uk

₹ Xiao Deng and Shilin Cao are co-first authors to this work.

This work was supported by the National Natural Science Foundation of China (21336002, 21222606, 21376096), the Key Program of Guangdong Natural Science Foundation (S2013020013049), the Fundamental Research Funds for the Chinese Universities (2015PT002, 2015ZP009), and the Program of State Key Laboratory of Pulp and Paper Engineering (2015C04).

DOI: 10.1016/S1872-2067(15)61045-2 | http://www.sciencedirect.com/science/journal/18722067 | Chin. J. Catal., Vol. 37, No. 4, April 2016
} 
ucts hinder its application in industry. To overcome these problems, techniques for the immobilization of the enzyme have been widely employed [4]. For the further development of the catalytic system, the ideal immobilization technique should meet the following requirements: (1) the enzyme carrier should have a high specific surface area, good biocompatibility, be easily recyclable and can bind large amounts of the active enzyme; (2) the immobilization process should be simple, rapid and facile; (3) the immobilized enzyme should exhibit good stability in the reaction system [5].

Magnetic iron oxide nanoparticles (MNPs) have attracted interest for their properties of biocompatibility, magnetism, high surface-to-volume ratio and low toxicity [6]. They have been used as an enzyme support for their high specific surface area and easy separation from the reaction mixture by an external magnet [7]. In most cases, the MNPs require a modification or functionalization to introduce the catalyst onto the surface.

Polydopamine, which is a polymer inspired by the composition of the adhesive protein in mussels, is one of the most commonly used biomimetic materials [8]. The primary advantage of polydopamine is that it can be easily deposited on virtually all types of inorganic and organic materials by the self-polymerization of its monomer dopamine [9-11]. Furthermore, many macromolecules (such as an enzyme) containing thiol or amine can be grafted on polydopamine by the Michael addition or Schiff base reaction between catechols (a moiety of polydopamine or dopamine) and amines or thiols [12]. Therefore, it is of interest to use polydopamine to surface modify MNPs because it can be expected that the polydopamine-coated MNPs (PD-MNPs) would be an excellent support for enzyme immobilization [13] due to these advantages: polydopamine exhibits good biocompatibility, the enzyme immobilization process is simple and natural $[14,15]$, and the immobilized enzyme can be easily and rapidly recycled with the use of a magnet.

Dihydromyricetin (DMY), a natural aglycone flavonoid, has been found to possess bioactivities with potential beneficial effects to the human body, such as anti-inflammatory, analgesic, antitussive, expectorant, antibacterial, anti-thrombotic and anti-tumor activities [16]. However, DMY is poorly soluble in aqueous and nonaqueous systems, which limits its processing and application. Our research group [17] has reported the lipase catalytic acylation of DMY, and shown that the solubility of the product in organic solvents and lipid systems was significantly improved. However, to meet the requirements of industrial production, the reusability of the lipase needed to be improved.

In this study, MNPs were prepared and surface-modified by a polydopamine coating. The polydopamine-coated MNPs (PD-MNPs) were structurally characterized in detail. The lipase from Aspergillus niger (ANL) was immobilized on the PD-MNPs with a high activity recovery rate and protein loading. The enzymatic properties of the immobilized lipase (ANL@PD-MNPs) were investigated systematically. The ANL@PD-MNPs were used as a magnetic recyclable biocatalyst for the regioselective acylation of dihydromyricetin (DMY).

\section{Experimental}

\subsection{Materials}

Dopamine hydrochloride was purchased from Aladdin. Ferric chloride hexahydrate $\left(\mathrm{FeCl}_{3} \cdot 6 \mathrm{H}_{2} \mathrm{O}\right)$ and ferrous chloride tetrahydrate $\left(\mathrm{FeCl}_{2} \cdot 4 \mathrm{H}_{2} \mathrm{O}\right)$ were obtained from Guangzhou Chemical Reagent Co. Ltd. Aspergillus niger lipase was purchased from Shenzhen Leveking Bio-Engineering Co. Ltd. (Shenzhen, China). DMY was obtained from Aladdin (Shanghai, China). Vinyl acetate (VA), used as acyl donor, was purchased from Sigma-Aldrich and TCI Co. Ltd. (Shanghai, China). All other reagents were analytical grade reagents and obtained from commercial sources.

\subsection{Preparation of MNPS}

The procedure for the preparation of MNPs was based on the conventional co-precipitation method with some modifications. In a typical experiment, $0.9 \mathrm{~g} \mathrm{FeCl}_{2} \cdot 4 \mathrm{H}_{2} \mathrm{O}$ and $2.43 \mathrm{~g}$ $\mathrm{FeCl}_{3} \cdot 6 \mathrm{H}_{2} \mathrm{O}$ were dissolved in $300 \mathrm{~mL}$ deionized water under $\mathrm{N}_{2}$ at room temperature. The $\mathrm{pH}$ of the solution was kept at 9.5 with $25 \%$ ammonia solution and vigorous stirring. After $1 \mathrm{~h}$, the magnetite precipitate was collected by an external magnet and washed three times with deionized water. The precipitate was dispersed in Tris- $\mathrm{HCl}$ buffer $(10 \mathrm{mmol} / \mathrm{L}, \mathrm{pH}=8.5)$ to MNPs of $2.7 \mathrm{mg} / \mathrm{mL}$ solution.

\subsection{Preparation of PD-MNPs}

The MNPs suspension prepared as described above was ultrasonicated for 20 min before dopamine hydrochloride (37.5 $\mathrm{mg}, 2.5 \mathrm{mg} / \mathrm{mL}$ ) was added to the MNP suspension. The $\mathrm{pH}$ of the solution was adjusted to 8.5 by the addition of $100 \mathrm{mmol} / \mathrm{L}$ $\mathrm{NaOH}$. After vigorous stirring for $1 \mathrm{~h}$, the PD-MNPs were separated by an external magnet and washed three times with deionized water and then dispersed in deionized water to PD-MNPs solution of $4.2 \mathrm{mg} / \mathrm{mL}$.

\subsection{Immobilization of Aspergillus niger lipase on the PD-MNPS}

Before immobilization, the PD-MNPs solution was ultrasonicated for $10 \mathrm{~min}$. In order to immobilize Aspergillus niger lipase (ANL), the suspension of PD-MNPs was added to a buffered lipase solution. An aqueous solution of ANL $(1.5 \mathrm{mg} / \mathrm{mL})$ was prepared by dissolving the ANL powder in sodium phosphate solution $(50 \mathrm{mmol} / \mathrm{L}, \mathrm{pH}=8.0)$. The freshly prepared PD-MNPs solution ( $2 \mathrm{~mL}, 4.2 \mathrm{mg} / \mathrm{mL}$ ) was added to the ANL solution ( $1 \mathrm{~mL}, 1.5 \mathrm{mg} / \mathrm{mL})$ at $0{ }^{\circ} \mathrm{C}$ in an ice bath. After stirring at $100 \mathrm{rpm}$ for $12 \mathrm{~h}\left(\right.$ at $\left.0{ }^{\circ} \mathrm{C}\right)$, the ANL-loaded precipitate was washed with deionized water and collected. The concentration of the residual ANL in the solution and the concentration of ANL in the washings were determined by the Bradford method [18]. The amount $(m)$ of ANL in the prepared ANL@PD-MNPs was calculated using the following equation:

$$
m=m_{0}-C_{1} V_{1}-C_{2} V_{2}
$$

where $m_{0}(\mathrm{mg})$ is the mass of ANL initially added to the solu- 
tion, $C_{1}(\mathrm{mg} / \mathrm{mL})$ is the residual ANL concentration of the solution, $V_{1}(\mathrm{~mL})$ is the volume of the solution, $C_{2}(\mathrm{mg} / \mathrm{mL})$ is the ANL concentration of the washings, and $V_{2}(\mathrm{~mL})$ is the volume of the washings. Finally the ANL@PD-MNPs was stored at $4{ }^{\circ} \mathrm{C}$.

\subsection{Activity assay of free ANL and ANL@PD-MNPS}

The enzymatic activity of free and immobilized lipase was measured by the para-nitrophenyl palmitate ( $p N P P)$ assay [19]. The basis of this assay protocol is the colorimetric estimate of para-nitrophenol ( $p \mathrm{NP})$ released as a result of the enzymatic hydrolysis of $p$ NPP at $405 \mathrm{~nm}$. In brief, an amount of free lipase or immobilized lipase was dispersed in $0.6 \mathrm{~mL}$ of sodium phosphate solution $(50 \mathrm{mmol} / \mathrm{L}, \mathrm{pH}=7.0)$ and subsequently mixed with $0.1 \mathrm{~mL}$ of $140 \mathrm{mmol} / \mathrm{L}$ para-nitrophenyl palmitate (in isopropanol) as the substrate. After 5 min of incubation at $35{ }^{\circ} \mathrm{C}$ with shaking at $100 \mathrm{rpm}$, the enzymatic reaction was terminated by the addition of $5.3 \mathrm{~mL}$ of ethanol. The free $p a-$ $r a$-nitrophenol was detected spectrophotometrically at 405 $\mathrm{nm}$. One unit (U) of lipase activity was defined as the amount of lipase which liberated $1 \mu \mathrm{mol}$ of para-nitrophenol per minute under the assay conditions. The activity recovery of the immobilized enzyme was calculated as the ratio of immobilized lipase activity to that of the amount of lipase added initially.

\subsection{Characteristics of free ANL and ANL@PD-MNPS}

In order to study the optimal $\mathrm{pH}$ and temperature for both free and immobilized lipase, their activities were measured over the $\mathrm{pH}$ range from 5 to 10 and temperature range from 20 to $80^{\circ} \mathrm{C}$.

The Michaelis-Menten constant $\left(K_{\mathrm{m}}\right)$ and maximum reaction rate $\left(V_{\max }\right)$ of both free and immobilized lipases and reusability of the immobilized lipase were determined as described previously [20]. In order to determine the kinetic parameters of free and immobilized lipase, the enzymatic hydrolysis of $p$ NPP was used as the model reaction. The initial reaction rates were determined under the optimum reaction conditions $(0.063$ $\mathrm{U} / \mathrm{mL}, 35^{\circ} \mathrm{C}, \mathrm{pH}=7.0$ for the free enzyme or $40{ }^{\circ} \mathrm{C}, \mathrm{pH}=8.0$ for the immobilized enzyme). The substrate concentration was varied from 20 to $180 \mathrm{mmol} / \mathrm{L}$. The Michaelis-Menten equation was used to fit the data (initial reaction rate versus substrate concentration). The kinetic parameters $\left(K_{\mathrm{m}}\right.$ and $\left.V_{\max }\right)$ of $p$ NPP hydrolysis with free or immobilized lipase were obtained from the fit.

To determine the pH stability and thermostability of the enzyme, ANL@PD-MNPs containing $20 \mu \mathrm{g}$ lipase or $20 \mu \mathrm{g}$ free lipase were incubated in sodium phosphate buffer (50 $\mathrm{mmol} / \mathrm{L})$ adjusted to various $\mathrm{pH}$ values $\left(\mathrm{pH}=6-10\right.$ at $\left.40{ }^{\circ} \mathrm{C}\right)$ and various temperatures $\left(40-80{ }^{\circ} \mathrm{C}, \mathrm{pH}=7\right)$. The incubation times to test the stability of the enzyme were 12 and $8 \mathrm{~h}$ for the pH stability and thermostability, respectively. The residual activity of both free and immobilized lipases was determined as above.

To investigate the solvent tolerance of the free and immobilized enzymes, lipase immobilized on MNPs containing $50 \mathrm{U}$ lipase or $50 \mathrm{U}$ free lipase was incubated in $3 \mathrm{~mL}$ of solvent (ac- etonitrile, DMSO, ethanol or [HMIm]BF 4 ) at $30{ }^{\circ} \mathrm{C}$ for $6 \mathrm{~h}$. The residual activity of the enzyme was assayed by the method described above.

\subsection{Secondary structure analysis of free ANL and ANL@PD-MNPs by infrared spectroscopy}

The IR spectra of free ANL and ANL@PD-MNPs were obtained by the same method previously described. The FT-IR spectra were measured from 4000 to $400 \mathrm{~cm}^{-1}$ with powder samples dispersed in a pressed $\mathrm{KBr}$ disc using a Tensor 37 spectrometer (Bruker, Germany) equipped with a deuterated triglycine sulfate (DTGS) detector. This equipment was controlled by the Bruker OPUS software. The subtraction of residual vapor absorption was also performed as necessary. The background spectra were recorded in the absence of the enzyme. The enzyme spectra were corrected by the subtraction of the background spectra. Curve fitting of the amide I region (1600 to $1700 \mathrm{~cm}^{-1}$ ) first used smoothing with a 13-point Savitzky-Golay filter and identified using the secondary derivative. A multiple peak fitting program with a Gaussian function in the PeakFit 4.2 software (Jandel Scientific) was used to quantify the multicomponent peak areas of the protein amide I bands. The relative contents of the $\alpha$-helix structure (1650-1658 $\mathrm{cm}^{-1}$ ), $\beta$-sheet structure (1610-1640 $\mathrm{cm}^{-1}$ ), random coil structure $\left(1640-1650 \mathrm{~cm}^{-1}\right)$, and $\beta$-turn structure (1660-1700 $\mathrm{cm}^{-1}$ ) based on the multicomponent peak areas were calculated according to the procedure described in the literature for the software [21].

\subsection{Use of ANL@PD-MNPs for the regioselective acylation of $D M Y$}

During the regioselective acylation process of DMY, $60 \mathrm{U}$ of free ANL or ANL@PD-MNPs was added to $2 \mathrm{~mL}$ of DMSO, followed by the addition of DMY and vinyl acetate to the final concentrations of 0.04 and $0.4 \mathrm{mmol} / \mathrm{L}$, respectively. The mixture was incubated at $35{ }^{\circ} \mathrm{C}$ in an orbital shaking water bath (200 rpm) for up to $48 \mathrm{~h}$. Aliquots were withdrawn at specific time intervals. The reaction mixture was analyzed by RP-HPLC on a $4.6 \mathrm{~mm} \times 250 \mathrm{~mm}$ ( $5 \mu \mathrm{m}$ coating thickness) Zorbax SB-C18 column (Agilent Technology Industries Co., Ltd.) using a Waters HPLC system consisting of two Waters 1525 pumps and a Waters 2489 UV detector set at $294 \mathrm{~nm}$. Elution was performed with a gradient system comprising $0.1 \%$ acetic acid and $100 \%$ methanol as solvents $A$ and $B$, respectively. Elution began with $28 \%$ solvent $B$, which was increased to $30 \%$ between 0 and 6 $\mathrm{min}$, and then to $80 \%$ between 6 and $12 \mathrm{~min}$, and finally returned to $28 \%$ between 12 and $13 \mathrm{~min}$. The peak of DMY (which eluded at $6.68 \mathrm{~min}$ ) was detected by HPLC. The conversion $(C)$ of DMY was calculated by

$$
C=\left(C_{0}-C_{\mathrm{s}}\right) / C_{0} \times 100 \%
$$

where $C_{0}$ and $C_{\mathrm{s}}$ were the initial and terminal concentration of DMY, respectively.

To study the effect of the molar ratio of vinyl acetate to DMY on the reaction, acylation reactions were conducted in $2 \mathrm{~mL}$ DMSO with the addition of $60 \mathrm{U}$ free ANL or ANL@PD-MNPs. 
The molar ratio of vinyl acetate to DMY was varied from 2.5 to 25 . To investigate the effect of temperature on the reaction, acylation reactions were conducted under the same conditions as above except that the molar ratio of vinyl acetate to DMY was fixed at 1 to $10(0.04 \mathrm{mmol}$ DMY and $0.4 \mathrm{mmol}$ vinyl acetate). The reaction temperature was varied between 30 and 50 ${ }^{\circ} \mathrm{C}$. To study the effect of enzyme concentration on the reaction, acylation experiments were conducted under the same conditions as above except that the temperature was fixed at $45^{\circ} \mathrm{C}$ and the molar ratio of DMY to vinyl acetate was fixed at 1 to 10 . The amount of enzyme was varied from 10 to $100 \mathrm{U}$.

The activity stability of immobilized lipase during the regioselective acylation process of DMY was studied under the same conditions as described in the previous section. After each enzyme run, the ANL@PD-MNPs were magnetically isolated and washed with hexane and ultrapure water to remove any remaining substrate and product before the next experiment. The residual activity of the immobilized lipase after each cycle was expressed as a percentage of the activity at the beginning of the experiment. All data reported in this study were averages of experiments performed at least in triplicate with no more than $3.0 \%$ experimental error.

\section{Results and discussion}

\subsection{Synthesis and analysis of MNPS and PD-MNPs}

TEM images of the MNPs and PD-MNPs are shown in Fig. 1. The MNPs were spherical with the average diameter of $10 \mathrm{~nm}$ (Fig. 1(a)). The fact that the MNPs were aggregated was consistent with their having a large specific surface area and high surface energy. After coating with polydopamine (polymerization time $1 \mathrm{~h}$ ), it was clearly observed that the dark MNPs were uniformly encapsulated in the light gray polydopamine layer (Fig. 1(b)). The MNPs showed a tendency to aggregate due to the interaction between polydopamine and MNPs. The average thickness of the polydopamine coating around the edge of the MNP aggregates in the hybrid material was $4 \mathrm{~nm}$. Fig. 1(c) shows a TEM image of the ANL@PD-MNPs. The mean size of the aggregates of PD-MNPs with immobilized lipase was $25 \mathrm{~nm}$, which was obviously larger than that of the PD-MNPs without the enzyme. The sizes of the MNPs, PD-MNPs and ANL@PD-MNPs were also determined by dynamic light scattering (DLS). The size distribution is depicted in Fig. $1(d, e, f)$. The mean sizes of the MNPs, PD-MNPs and ANL@PD-MNPs were 9.6, 13.8 and $26.1 \mathrm{~nm}$, respectively, which were consistent with those observed in the TEM images.

XPS was applied to investigate the chemical elements on the surface of MNPs and PD-MNPs. The energy scale was calibrated with the C 1 s peak (284.8 eV). Wide scan XPS spectra for the MNPs and PD-MNPs are shown in Fig. 2(a) and (b). The characteristic peaks of Fe $2 p$ (Fe $2 p_{1 / 2} 724.38 \mathrm{eV}$, Fe $2 p_{3 / 2} 710.58 \mathrm{eV}$ ) and $\mathrm{O} 1 s(530.08 \mathrm{eV})$ appeared in the spectrum due to $\mathrm{Fe}_{3} \mathrm{O}_{4}$. The weak peak of $\mathrm{C} 1 \mathrm{~s}$ was attributed to the presence of impurities [22]. After the MNPs were coated with polydopamine, the peak of C $1 s$ was enhanced significantly (boxed in red in Fig. 2(b)), and that of $01 s$ was reduced somewhat due to the high
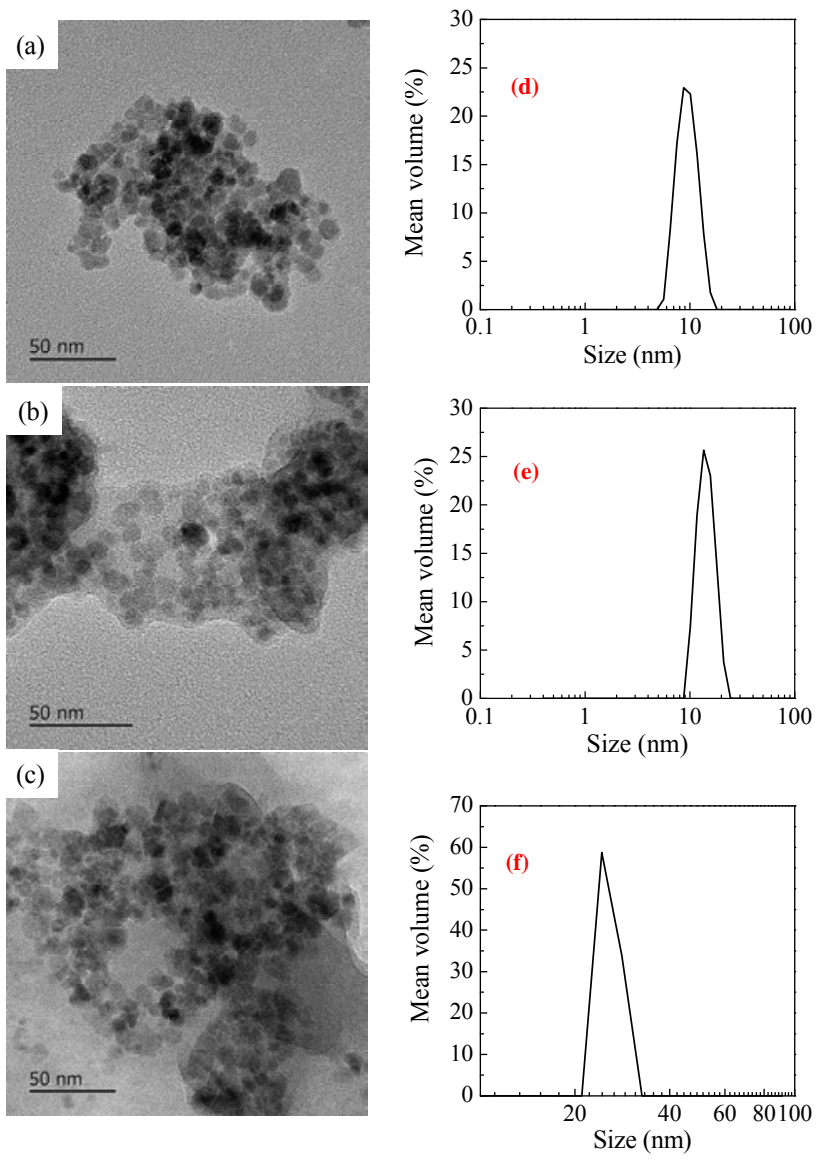

Fig. 1. TEM images and size distribution of MNPs (a, d), PD-MNPs (b, e) and ANL@PD-MNPs (c, f).

content of carbon and low content of oxygen in polydopamine. Meanwhile, the appearance of the characteristic N $1 s$ weak peaks at the expected positions at $399.08 \mathrm{eV}$ (also boxed in red in Fig. 2(b)) confirmed the presence of nitrogen contained in the polydopamine. The data in Fig. 2(b) indicated that the PD-MNPs exhibited an N/C ratio of 0.106, which is close to the $\mathrm{N} / \mathrm{C}$ ratio of 0.125 (dopamine). Fig. 2(c) and (d) shows high resolution scan spectra of the $\mathrm{C} 1 s$ and $\mathrm{N} 1 s$ regions, respectively, of the PD-MNPs after XPS peak deconvolution and fitting. The $\mathrm{C} 1 s$ peak contained $\mathrm{C}-\mathrm{C}(284.8 \mathrm{eV}), \mathrm{C}-\mathrm{N}(285.8 \mathrm{eV}), \mathrm{C}-\mathrm{O}$ $(286.3 \mathrm{eV})$ and $\mathrm{C}=\mathrm{O}(287.8 \mathrm{eV})$ peaks and the $\mathrm{N} 1 s$ region was made up of $\mathrm{N}-\mathrm{H}(398.7 \mathrm{eV})$ and $-\mathrm{N}=(399.7 \mathrm{eV})$ peaks, which were in accordance with previously published XPS results of polydopamine [23]. Taken together, the XPS results demonstrated that the MNPs were successfully covered by polydopamine.

The FT-IR spectra displayed in Fig. 3 were recorded to confirm the chemical composition of the PD-MNPs. A strong peak appearing at $580 \mathrm{~cm}^{-1}$ and a weak one at $436 \mathrm{~cm}^{-1}$ in the spectra of both the MNPs and PD-MNPs were due to the vibration of the Fe-O functional group. The relatively high intensity of the band at $580 \mathrm{~cm}^{-1}$ indicated the high content of $\mathrm{Fe}_{3} \mathrm{O}_{4}$ [24]. In addition, a weak band appearing at $1255 \mathrm{~cm}^{-1}$ in spectrum (2) in Fig. 3 was attributed to the phenolic hydroxyl group stretching mode of the polydopamine layer. For the PD-MNPs, this 

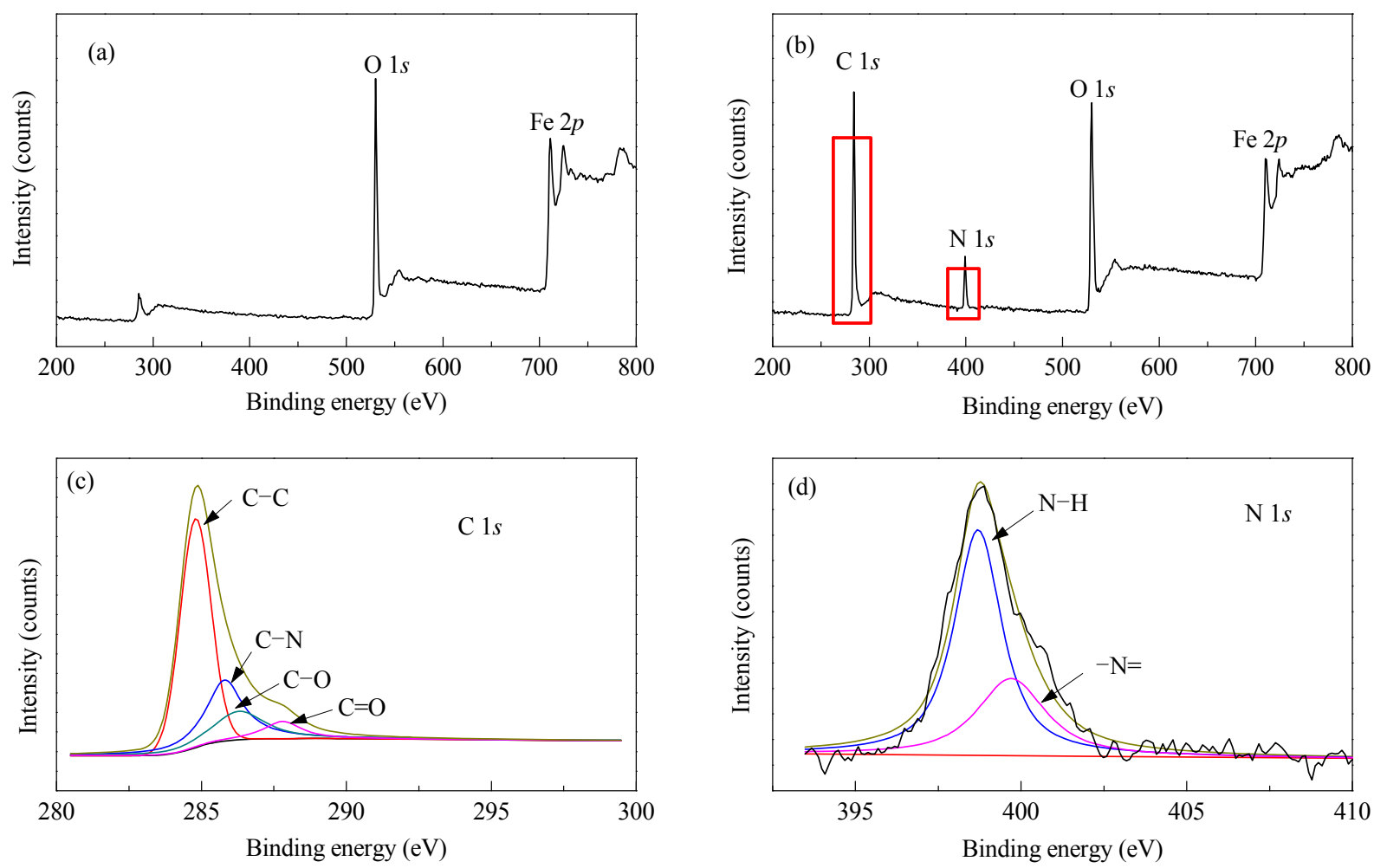

Fig. 2. (a) Wide XPS scan of MNPs; (b) Wide XPS scan of PD-MNPs; (c) Narrow scan XPS spectrum of the C $1 s$ region of the PD-MNPs; (d) Narrow scan XPS spectrum of the $\mathrm{N} 1 s$ region of the PD-MNPs.

signal appeared and showed the interaction between the hydroxyl and aromatic rings. The vibrational signals at 1610 and $1490 \mathrm{~cm}^{-1}$ were ascribed to $\mathrm{C}=\mathrm{C}$ in aromatic rings. The peak at $1428 \mathrm{~cm}^{-1}$ of the PD-MNPs was broader than that of MNPs, which results from the overlapping of $\mathrm{O}=\mathrm{C}-\mathrm{O}$ symmetric vibration $\left(1405 \mathrm{~cm}^{-1}\right)$ and the indoline peak of polydopamine (1438 $\left.\mathrm{cm}^{-1}\right)$ [25].

Fig. 4(1) shows the XRD patterns of the MNPs. Similar to the previous report [26], the XRD pattern showed six diffraction peaks in the $2 \theta$ range of $20^{\circ}-70^{\circ}$, including a high intensity sharp peak at $2 \theta=35.6^{\circ}$, corresponding to the (311) plane, and five additional weak peaks at $2 \theta=30.6^{\circ}, 43.4^{\circ}, 54.4^{\circ}, 56.7^{\circ}$ and $62.7^{\circ}$, corresponding to the (220), (400), (422), (411) and (440) planes, respectively, showing the presence of the mag-

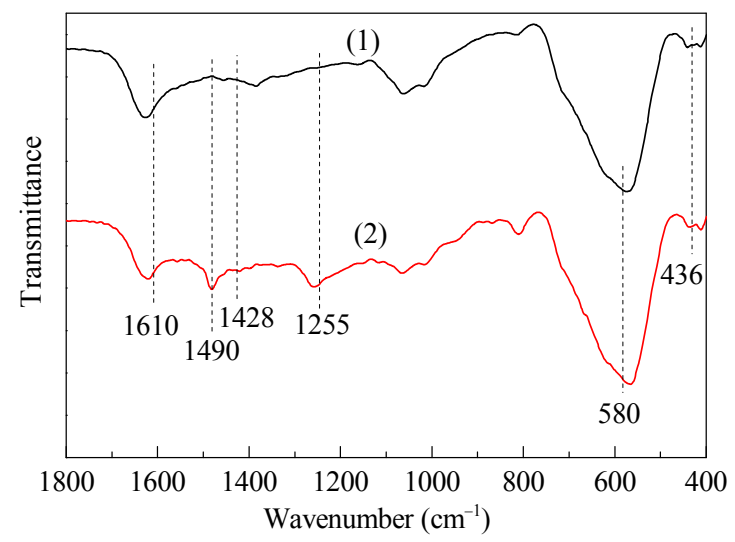

Fig. 3. FT-IR spectra of MNPs (1) and PD-MNPs (2). netite crystal with a cubic spinal structure [27]. The unit cell of the cubic spinal structure consists of eight ferric ions at tetrahedral sites each with four oxide ion nearest neighbors, and eight ferric ions and eight ferrous ions at octahedral sites each with six oxide ions as the nearest neighbors [28]. The XRD pattern of the PD-MNPs (Fig. 4(2)) showed that the crystal structure of $\mathrm{Fe}_{3} \mathrm{O}_{4}$ was maintained after the coating process. No obvious diffraction peak for the polydopamine was observed, which may be due to the relatively thin layer and amorphous structure of the polydopamine prepared with this polymerization method [29].

The polydopamine (PDA), MNPs and PD-MNPs were analyzed by TGA analysis in a nitrogen atmosphere with a heating rate of $10^{\circ} \mathrm{C} / \mathrm{min}$. Fig. 5 illustrates the TGA curves depicting the

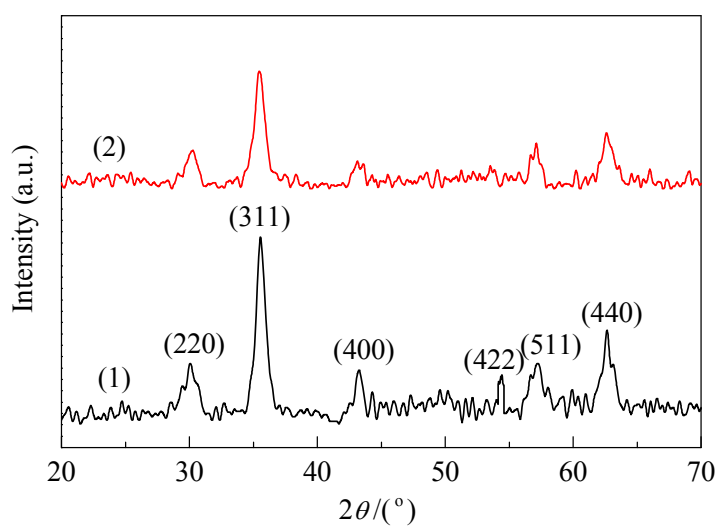

Fig. 4. XRD patterns of the MNPs (1) and PD-MNPs (2). 
variation of the mass of the sample with temperature. The first mass loss (below $130{ }^{\circ} \mathrm{C}$ ) of the polydopamine sample (Fig. $5(\mathrm{a})(1)$ ) can be ascribed to the evaporation of water molecules in the polymer matrix while the other mass loss beginning at about $190{ }^{\circ} \mathrm{C}$ was due to the decomposition of polydopamine. As the PDA content of the materials increased (Fig. 5(a)(3-5)), the proportion of the mass lost due to thermal decomposition of the PDA increased also. As shown in Fig. 5(b), when the concentration of dopamine hydrochloride was up to $4.0 \mathrm{mg} / \mathrm{mL}$, the mass loss of the PD-MNPs on heating was $24.4 \%$.

The PD-MNPs can be separated and purified from the solvent by using a magnet (Fig. 6(a)). The vibrating specimen magnetometer (VSM) magnetization curves of the MNPs and PD-MNPs (Fig. 6(b)) indicated no remanence or coercivity, suggesting that the MNPs and PD-MNPs were superparamagnetic. Saturation magnetization is defined as the maximum magnetic response of a material in an external magnetic field which can be used to estimate the magnetism of the material [30,31]. Consistent with their superparamagnetic behavior, the MNPs and PD-MNPs showed high saturation magnetization of 60.1 and $52.7 \mathrm{emu} / \mathrm{g}$, respectively. The lower saturation magnetization of the PD-MNPs compared with the MNPs was consistent with their smaller proportion of magnetic material due to the presence of the polydopamine coating. Nonetheless, the magnetic properties of the PD-MNPs were sufficient to provide an easy and effective way to isolate them from the liquid reaction system.

\subsection{Immobilization of free ANL onto PD-MNPS}

During the immobilization process, the activity recovery and the protein loading were affected by the $\mathrm{pH}$ and immobilization time. Therefore, these two factors were varied in order to maximize the immobilization capacity and enzyme activity. As the $\mathrm{pH}$ was increased from 6 to 9, the amount of lipase immobilized on the PD-MNP support increased from 26.3 to 138.1 $\mathrm{mg} / \mathrm{g}$. The proportion of enzyme activity remaining after immobilization dropped off above $\mathrm{pH}=8$ (Fig. 7(a)). Hence, under the conditions tested, $\mathrm{pH}=8$ was optimal for the immobilization of the enzyme because, while protein immobilization continued to become more effective with increasing $\mathrm{pH}$ beyond this, the enzyme began to become deactivated. The immobilization time also influenced the properties of the immobilized biocatalyst. As the immobilization time was increased, the amount of enzyme loaded on the PD-MNPs and the proportion of activity remaining after immobilization showed maximum
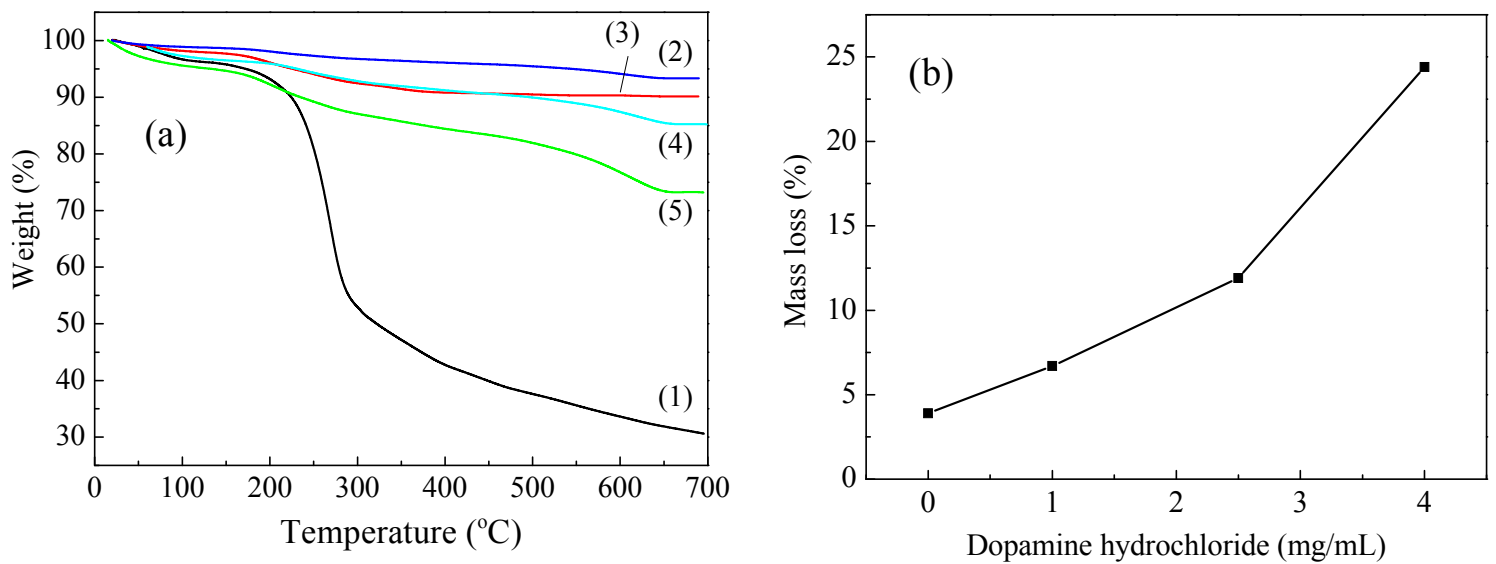

Fig. 5. (a) Mass loss curves of (1) PDA, (2) MNPs, (3) PD-MNPs (dopamine hydrochloride $1 \mathrm{mg} / \mathrm{mL}$ ), (4) PD-MNPs (dopamine hydrochloride 2.5 $\mathrm{mg} / \mathrm{mL}$ ), and (5) PD-MNPs (dopamine hydrochloride $4.0 \mathrm{mg} / \mathrm{mL}$ ); (b) Effect of concentration of dopamine hydrochloride on the mass loss of PD-MNPs (at $700^{\circ} \mathrm{C}$ ).
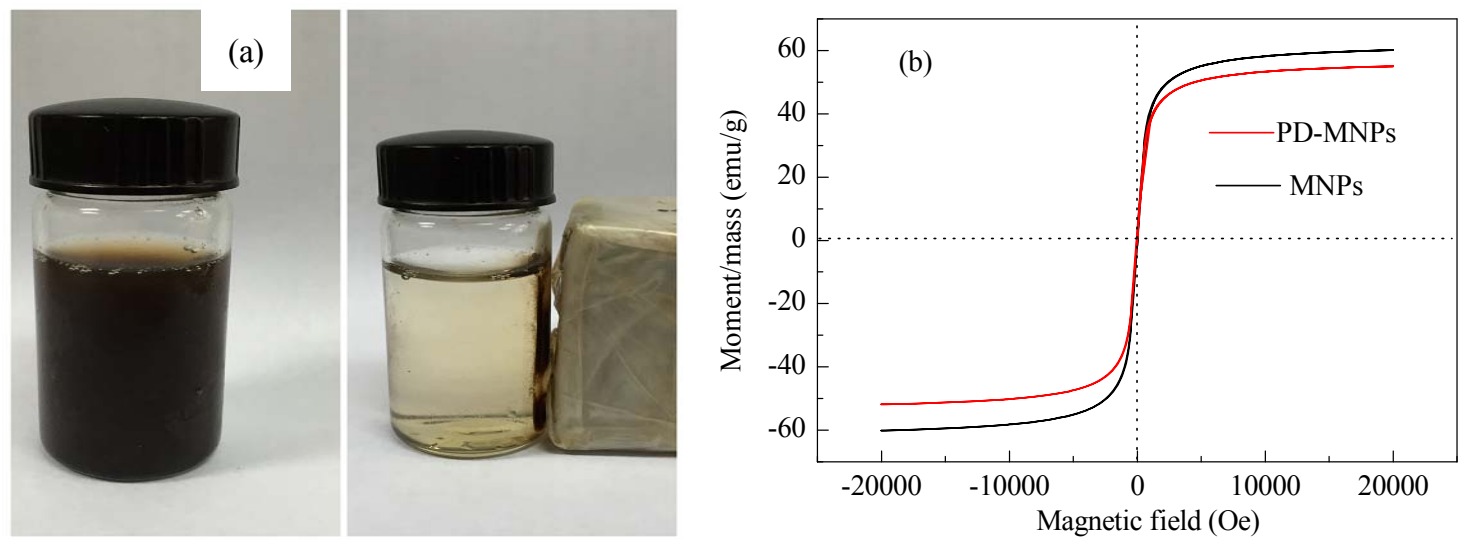

Fig. 6. (a) PD-MNPs dispersed in aqueous solution (left) and PD-MNPs attracted by an external magnet (right); (b) Hysteresis loops of magnetic MNPs and PD-MNPs. 
values after $12 \mathrm{~h}$ of immobilization, with $138 \mathrm{mg} / \mathrm{g}$ of enzyme immobilized and $83.6 \%$ retention of activity (Fig. 7(b)). The decrease in the retention of activity after a longer immobilization time may be related to the steric hindrance of substrate access to the enzyme at high enzyme loading on the solid support [32].

\subsection{Characteristics of free ANL and ANL@PD-MNPs}

Immobilization resulted in a change in the $\mathrm{pH}$ activity profile of the lipase (Fig. 8(a)) such that the range over which the lipase retained more than $85 \%$ of enzyme activity, which was widened slightly from $\mathrm{pH}=7$ to 8 for the free ANL to $\mathrm{pH}=7$ to 8.5 for the ANL@PD-MNPs. The optimum pH shifted from $\mathrm{pH}=$ 7 to 8 upon immobilization. The interactions between the enzyme and the polymeric matrix, such as hydrogen bonding and electrostatic interactions, can explain the observed alkaline shift and broadening in the $\mathrm{pH}$ profile of the immobilized lipase [33]. Similar results upon immobilization of lipase and other enzymes have been reported previously [34]. In particular, compared with free ANL, the ANL@PD-MNPs exhibited a considerably higher activity at $\mathrm{pH}=10(64.3 \%$ of the maximum activity), while its free counterpart only had $24.6 \%$ of the maximum activity at this $\mathrm{pH}$. Hence, the ANL@PD-MNPs exhibited improved activity across a wider $\mathrm{pH}$ range, especially in weakly alkaline media.

Fig. 8(b) shows the effect of temperature on the activity of free ANL and ANL@PD-MNPs. The activity obtained in the temperature range of $20-80{ }^{\circ} \mathrm{C}$ were expressed as percentage of the maximum activity recorded at 35 and $40{ }^{\circ} \mathrm{C}$ for free ANL and ANL@PD-MNPs, respectively (percentage of the activity at the optimum temperature for each form of the enzyme). Above $50{ }^{\circ} \mathrm{C}$, the relative activity of free ANL dropped sharply and it retained only $26.7 \%$ at $80{ }^{\circ} \mathrm{C}$. In contrast, the ANL@PD-MNPs retained $54.4 \%$ of the activity at $80{ }^{\circ} \mathrm{C}$. The increase in the optimum temperature of the immobilized enzyme may have resulted from the changing conformational integrity of the lipase structure by covalent bond formation between the enzyme and solid support via amino groups. During the immobilization, if the flexibility of the enzyme molecule is decreased, the enzyme would require a higher activation energy to reorganize to the appropriate conformation for catalysis [35]. The ANL@PDMNPs showed enhanced heat resistance at high temperature $\left(>70{ }^{\circ} \mathrm{C}\right)$, possibly because of restricted conformational mobility of the molecules which protect against thermal denaturation [36]. Therefore, the activity of the ANL@PD-MNPs was higher than its free counterpart at high temperatures. Similar results of improved activity at high temperatures after enzyme immobilization have also been observed previously [37].

In order to study the $\mathrm{pH}$ stability of the free ANL and
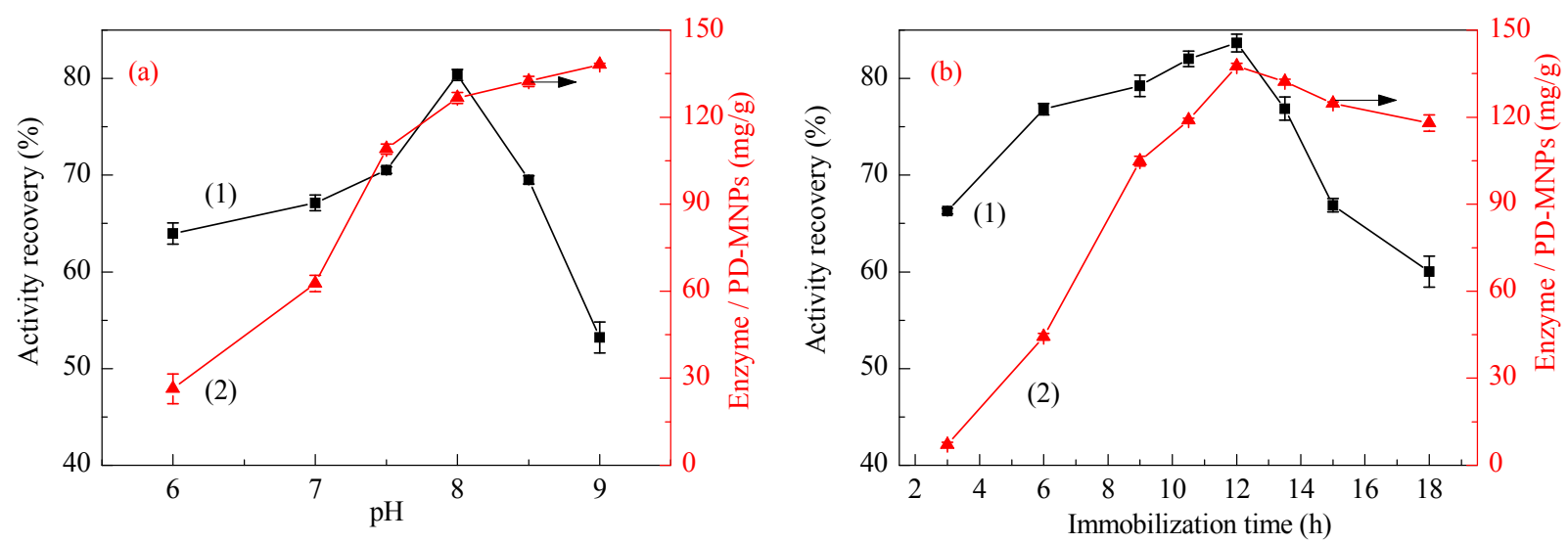

Fig. 7. Effects of immobilization conditions on the activity recovery (1) and protein loading (2). (a) Effect of pH (1.5 mg lipase, 3 mg PD-MNPs, 2.5 $\mathrm{mg} / \mathrm{mL}$ dopamine hydrochloride, polymerization time $1 \mathrm{~h}$; immobilization time $9 \mathrm{~h}$ ); (b) Effect of immobilization time (1.5 mg lipase, 3 mg PD-MNPs, $2.5 \mathrm{mg} / \mathrm{mL}$ dopamine hydrochloride, polymerization time $1 \mathrm{~h} ; \mathrm{pH}=8.0$ ).
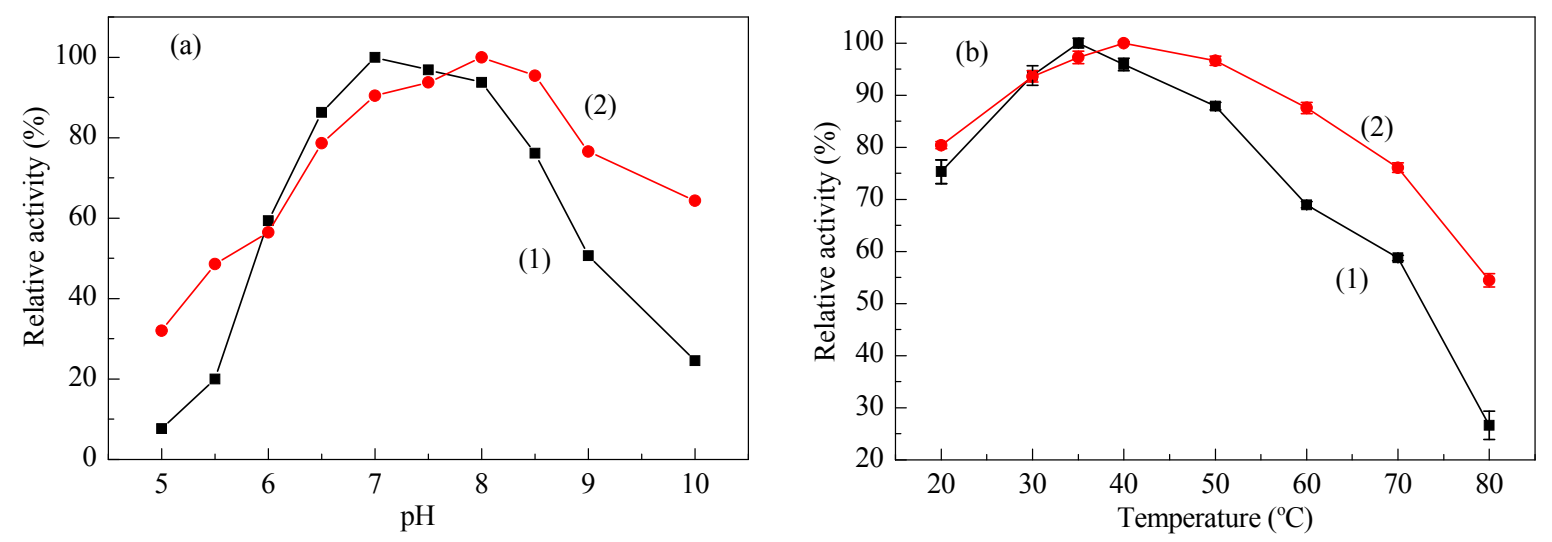

Fig. 8. Optimal pH (a) and temperature (b) of ANL@PD-MNPs (2) and free ANL (1). 
ANL@PD-MNPs over a period of time, the enzyme was incubated at $40{ }^{\circ} \mathrm{C}$ for $12 \mathrm{~h}$ in phosphate buffer ( $50 \mathrm{mmol} / \mathrm{L}, \mathrm{pH}$ varied over the range 6-10) (Fig. 9(a)). The ANL@PD-MNPs retained $49.1 \%$ of its initial activity after $12 \mathrm{~h}$ incubation at $\mathrm{pH}$ $=10$, while the final activity of the free ANL was only $22.9 \%$ of the initial value. This indicated that the ANL@PD-MNPs exhibited enhanced $\mathrm{pH}$ stability.

The thermal stability of free ANL and ANL@PD-MNPs was investigated as a function of time at different temperatures between 40 and $80{ }^{\circ} \mathrm{C}$. As seen in Fig. 9(b), the ANL@PD-MNPs retained more than $83.5 \%$ of its initial activity after incubation for $8 \mathrm{~h}$ at $40{ }^{\circ} \mathrm{C}$, while less than $71 \%$ of residual activity was detected with the free ANL after the same treatment. As mentioned above, the conformational rigidity of lipase would have been strengthened by immobilization, thus enhancing its thermal stability.

Both the free ANL and ANL@PD-MNPs were stored at $4{ }^{\circ} \mathrm{C}$ in $\mathrm{pH}=7$ phosphate buffer for $20 \mathrm{~d}$ in order to investigate the enzymatic storage stability. Compared to the free ANL, the ANL@PD-MNPs exhibited excellent retention of activity under these conditions, as can clearly be seen by the fact that after 20 d of storage, the ANL@PD-MNPs retained 92.8\% of its original activity, while the free counterpart retained only $21.5 \%$ under the same conditions (Fig. 9(c)).

Compared with the free ANL, the ANL@PD-MNPs exhibited significantly better tolerance to all four solvents tested (Fig. 9(c)). The difference in retention of activity between the free ANL and ANL@PD-MNPs increased with an overall degree of inhibition caused by the solvent during the $6 \mathrm{~h}$ incubation period at $40{ }^{\circ} \mathrm{C}$. Hence, the least inhibitory solvent ethanol per-
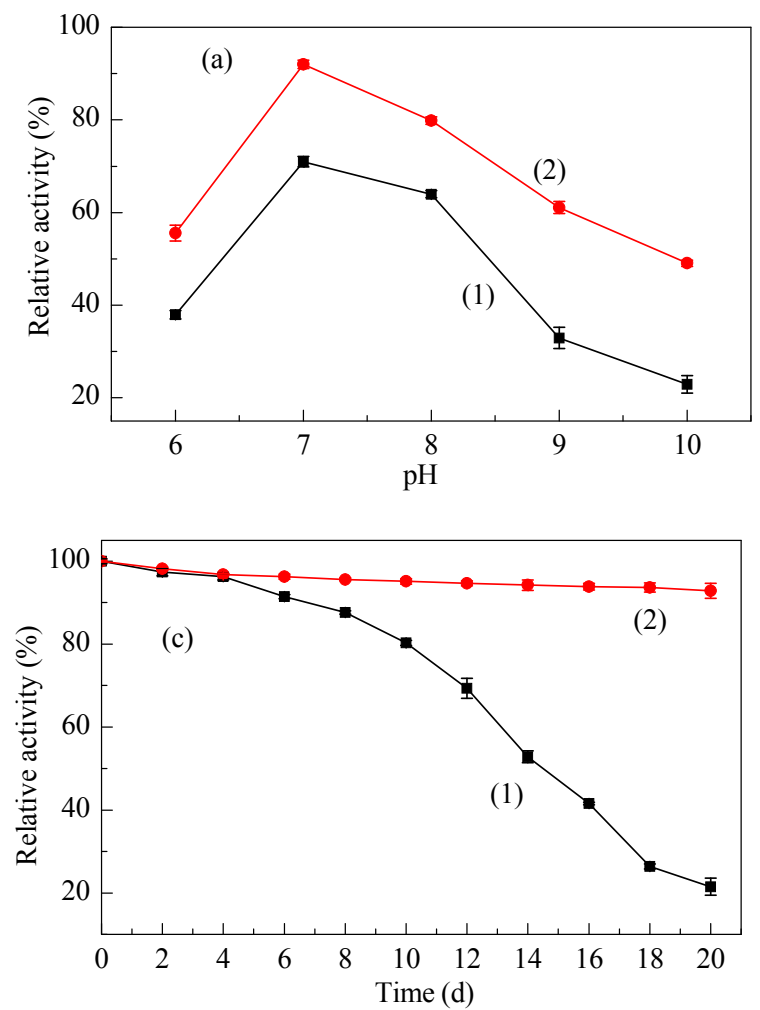

mitted retention of $90.48 \%$ and $81.30 \%$ of the initial activity by the free ANL and ANL@PD-MNPs, respectively. In contrast after exposure to the most inhibitory solvent (the ionic liquid [HMIm] $\mathrm{BF}_{4}$ ), the ANL@PD-MNPs retained 63.19\% of its initial activity, while the free ANL retained only $35.79 \%$ of its initial activity. Owing to immobilization, the ANL@PD-MNPs maintained its catalytic conformation and exhibited more structural rigidity, resulting in enhanced solvent tolerance, which agreed with previous reports [38].

The kinetic behavior of the free ANL and ANL@PD-MNPs in the catalysis of $p$ NPP hydrolysis was investigated. Both reactions were found to follow Michaelis-Menten kinetics. $K_{\mathrm{m}}$ for free ANL and ANL@PD-MNPs was 74.5 and $63.2 \mathrm{mmol} / \mathrm{L}$, respectively, which demonstrated that the immobilized lipase had a moderately enhanced enzyme-substrate affinity [39]. The $V_{\max }$ for the ANL@PD-MNPs and the free ANL was $2.36 \times 10^{-2}$ and $3.03 \times 10^{-2} \mathrm{mmol} \mathrm{L}^{-1} \mathrm{~min}^{-1}$, indicating a slightly lower maximal rate for the ANL@PD-MNPs compared with the free ANL. This was consistent with the fact that the specific activity of the ANL@PD-MNPs was lower than that of the free ANL (1.58 U/mg vs $2.11 \mathrm{U} / \mathrm{mg}$ ).

The deconvolution of the amide I band from the FT-IR spectrum of the free ANL (Fig. 10(a)) has several distinct Lorentzian peaks. The band at $1628.41 \mathrm{~cm}^{-1}$ can tentatively be assigned to the $\beta$-sheet structure [40]. Following this assignment and according to deconvolution results, the $\beta$-sheet contribution constitutes $26.15 \%$ of the secondary structures in free ANL (Table 1). The band at $1656.24 \mathrm{~cm}^{-1}$ is characteristic of an $\alpha$-helical structure, and the area of this component accounts for $26.14 \%$ of the total band area in free ANL. The random coli $(29.78 \%)$
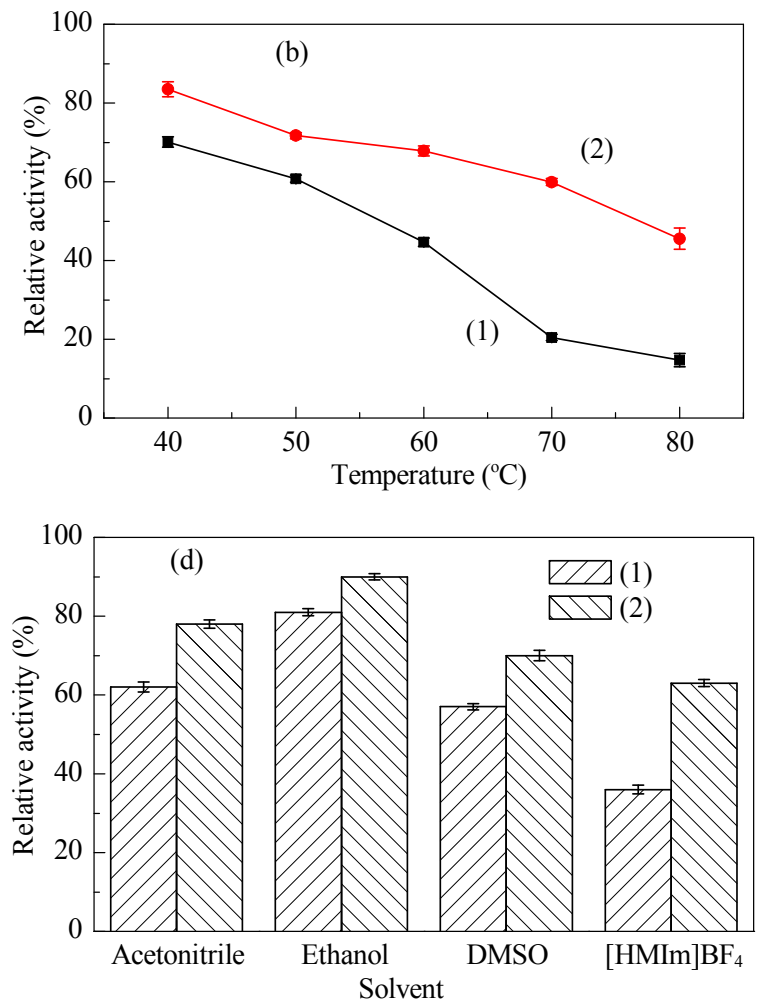

Fig. 9. Stabilities of ANL@PD-MNPs (2) and free ANL (1). (a) pH stability; (b) Thermal stability; (c) Storage stability; (d) Solvent tolerance. 

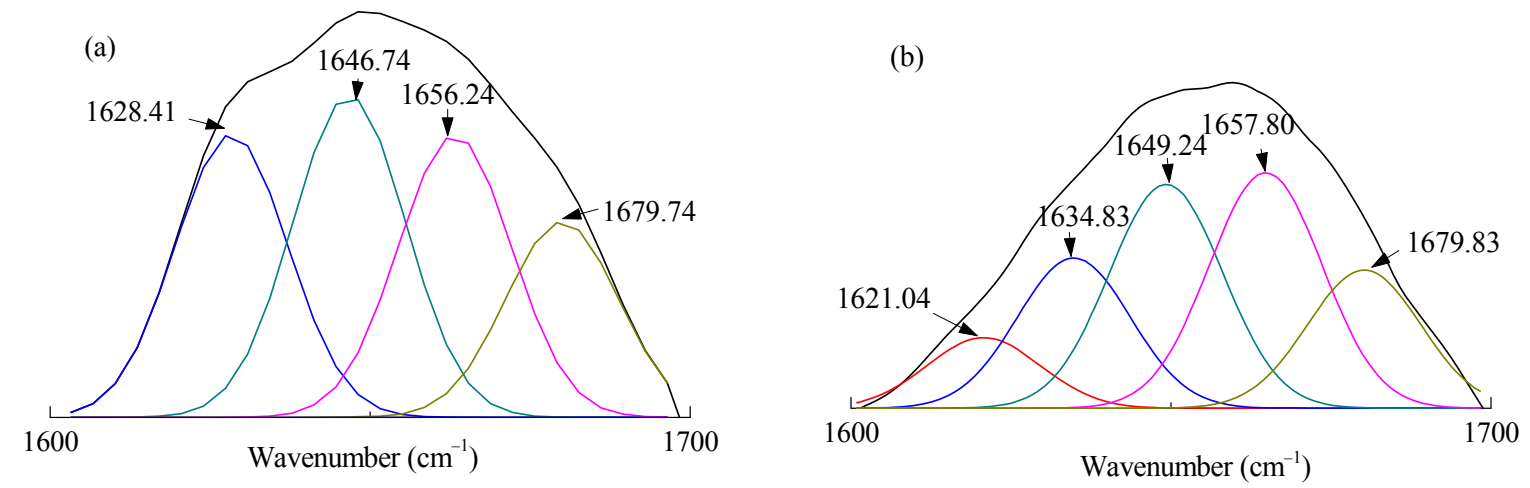

Fig. 10. Amide I fitting results of free ANL (a) and ANL@PD-MNPs (b).

Table 1

Amide I band deconvolution for free ANL and ANL@PD-MNPs.

\begin{tabular}{lcccc}
\hline \multirow{2}{*}{ sample } & \multicolumn{4}{c}{ Secondary structure (\%) } \\
\cline { 2 - 5 } & $\beta$-sheet & $\alpha$-helix & Random coli & $\beta$-turn \\
\hline Free ANL & 26.15 & 26.14 & 29.78 & 17.93 \\
ANL@PD-MNPs & 26.99 & 28.88 & 27.46 & 16.67 \\
\hline
\end{tabular}

and $\beta$-turns (17.93\%) contributed to the bands at 1646.74 and $1679.74 \mathrm{~cm}^{-1}$, respectively, in free ANL [41]. In the ANL@PD-MNPs (Fig. 10(b)), the Lorentzian bands of the deconvoluted amide I region at 1621.04 and $1634.83 \mathrm{~cm}^{-1}$ indicated $26.99 \%$ of the structure as $\beta$-sheets and the band at $1657.80 \mathrm{~cm}^{-1}$ suggested an $\alpha$-helix content of $28.88 \%$. This suggested an increase of $\beta$-sheet and $\alpha$-helix contents upon lipase immobilization of $2.74 \%$ and $0.84 \%$, respectively. The existence of hydrogen bonds within the secondary structure elements such as the $\beta$-sheet and $\alpha$-helix generally helps to maintain the protein structure $[42,43]$, which may be one reason why the ANL@PD-MNPs exhibited enhanced stability and improved tolerance to organic solvents and ionic liquid [44].

\subsection{Application of the ANL@PD-MNPs to the regioselective acylation of DMY}

As shown in Fig. 11(a), when the ANL@PD-MNPs was used as the biocatalyst for the acylation of DMY, the course for the regioselective acylation reaction was similar to that catalyzed by an equal number of units of the free ANL. The final conversion was $79.28 \%$ at $48 \mathrm{~h}$ with the ANL@PD-MNPs as biocatalyst and $69.47 \%$ with free ANL. The higher conversion with the immobilized lipase can be explained by the better organic solvent tolerance of the immobilized enzyme.

As shown in Fig. 11(b), the molar ratio of the substrate strongly affected the conversion rate of enzymatic DMY acylation. With the increase of the molar ratio of vinyl acetate (VA) to DMY from 2.5 to 10 , the conversion rate increased from $16.1 \%$ to $65.3 \%$ (free ANL) and from $20.3 \%$ to $70.6 \%$ (ANL@PD-MNPs). However, the conversion obtained from the free enzyme was retained at $70 \%$ when the molar ratio increased from 10 to 25 . Thus, the molar ratio of vinyl acetate to
DMY of 10 was selected for both free ANL and the ANL@PD-MNPs in the following experiment.

Temperature is a key parameter in the enzymatic acylation of DMY. With temperature increase from 30 to $45^{\circ} \mathrm{C}$, the conversion rate increased from $40.3 \%$ to $67.1 \%$ (free ANL) and 69.6\% to 79.1\% (ANL@PD-MNPs), respectively (Fig. 11(c)). Further increase in temperature had nearly no effect on the conversion rate. So the suitable temperature was $45^{\circ} \mathrm{C}$ for the following experiment.

Also, the enzyme concentration has a significant effect on the conversion. As shown in Fig. 11(d), when the amount of enzyme in the reaction mixture was increased from 10 to $40 \mathrm{U}$, the conversion increased obviously for both free ANL $(40.1 \%$ to 50.4\%) and ANL@PD-MNPs (65.3\% to 78.7\%). However, further increase in ANL@PD-MNP concentration had little effect on the conversion and the conversion rate remained at $78 \%$, indicating that the enzyme was saturated at $40 \mathrm{U}$ in the reaction. In contrast, free ANL was saturated at $80 \mathrm{U}$ and the corresponding conversion was 65\%, which showed that the ANL@PD-MNPs have better catalytic activity than free ANL.

Because the ANL@PD-MNPs can easily be isolated from the reaction system by an external magnet, its activity stability was investigated during 10 cycles of reuse (Fig. 12). The ANL@PD-MNPs retained more than $90 \%$ of its original catalytic activity in the regioselective acylation of DMY after four consecutive reaction cycles and $56 \%$ of the initial activity after ten cycles of reuse. This result strongly suggested that the ANL@PD-MNPs is applicable to repeated use as a biocatalyst.

\section{Conclusions}

MNPs were modified by a mussel-inspired polydopamine coating and characterized with respect to their morphology, composition, structure and magnetic properties. The PD-MNPs proved suitable for ANL immobilization and gave high protein loading and good activity recovery. The ANL@PD-MNPs showed improved $\mathrm{pH}$, thermal, solvent and storage stability compared to its free counterpart. The kinetic study of both the immobilized and free enzymes showed that the ANL@PD-MNPs have high catalytic efficiency. The ANL@PD-MNPs exhibited excellent reusability and kept over 

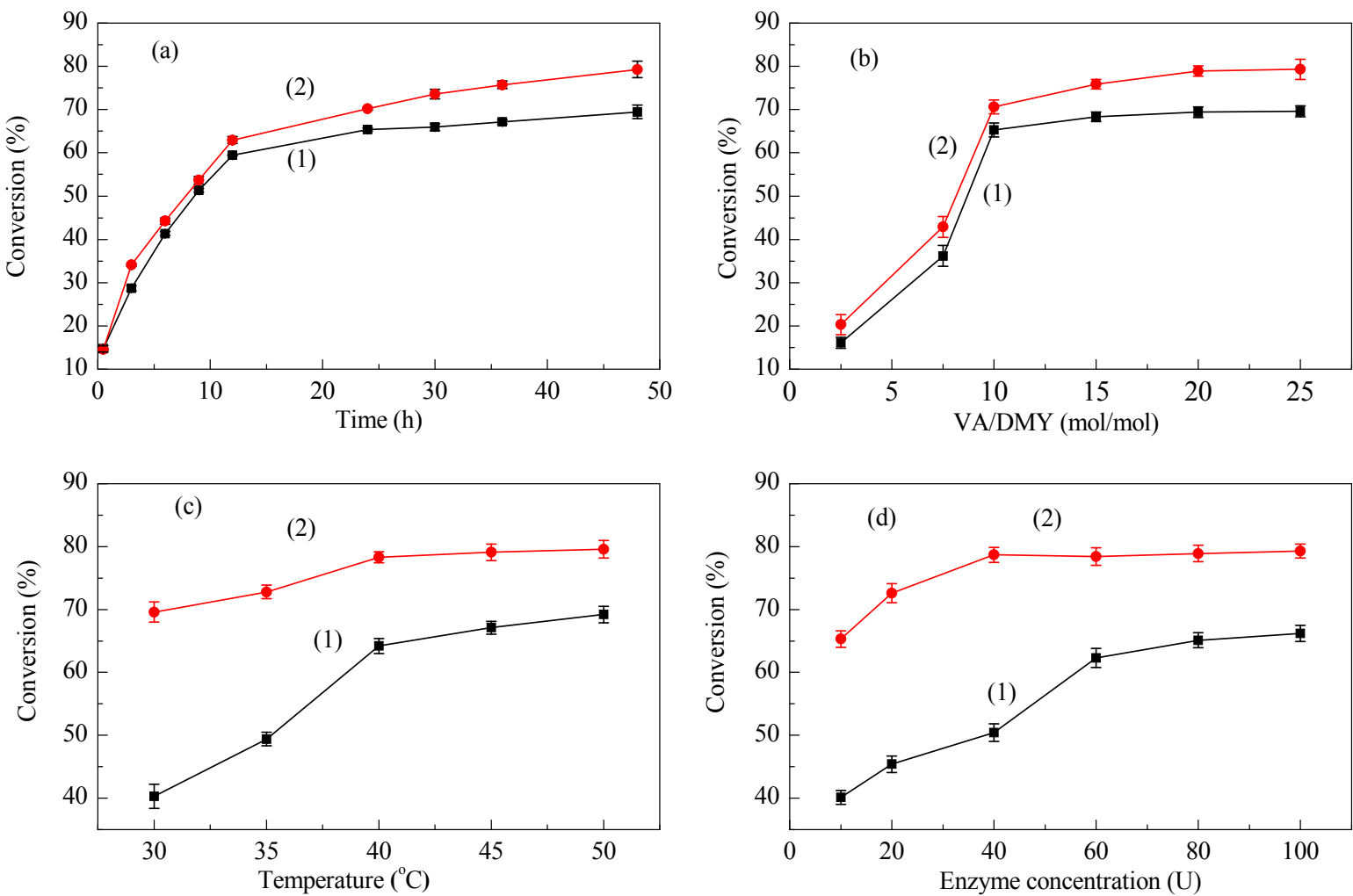

Fig. 11. (a) Enzymatic regioselective acylation of DMY catalyzed by ANL@PD-MNPs (2) and free ANL (1) (2 mL DMSO, $0.04 \mathrm{mmol}$ DMY, $0.4 \mathrm{mmol}$ vinyl acetate, $35^{\circ} \mathrm{C}, 200 \mathrm{rpm}, 60 \mathrm{U}$ ANL@PD-MNPs or free ANL); (b) Effect of molar ratio of substrates on the conversion $\left(2 \mathrm{~mL}\right.$ DMSO, $35^{\circ} \mathrm{C}, 200 \mathrm{rpm}$, 60 U ANL@PD-MNPs or free ANL); (c) Effect of temperature on the conversion (2 mL DMSO, $0.04 \mathrm{mmol}$ DMY, $0.4 \mathrm{mmol}$ vinyl acetate, $200 \mathrm{rpm}, 60 \mathrm{U}$ ANL@PD-MNPs or free ANL); (d) Effect of enzyme concentration on the conversion ( $2 \mathrm{~mL}$ DMSO, $0.04 \mathrm{mmol}$ DMY, $0.4 \mathrm{mmol}$ vinyl acetate, $200 \mathrm{rpm}$, $\left.45^{\circ} \mathrm{C}\right)$.

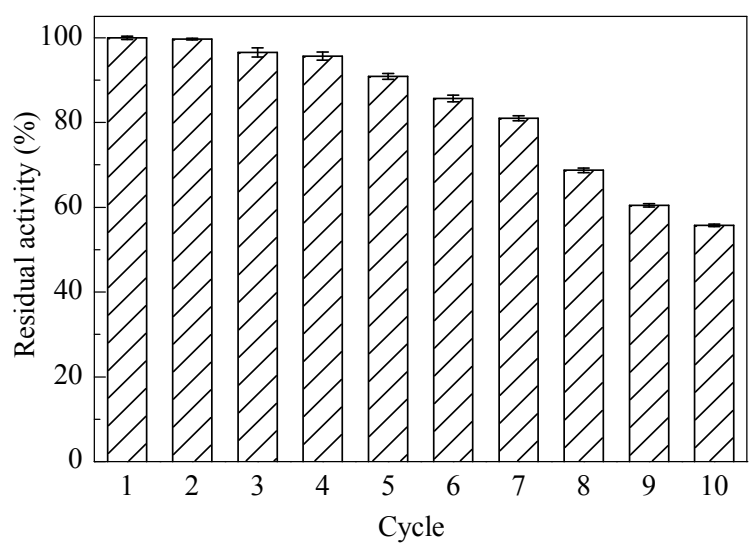

Fig. 12. The operational stability of ANL@PD-MNPs.

$55 \%$ of its initial activity after 10 cycles of reuse during the regioselective acylation process of DMY with convenient magnetic recovery of the biocatalyst.

\section{References}

[1] A. Salihu, Md. Z. Alam, Process Biochem., 2015, 50, 86-96.

[2] M. Masomian, R. N. Z. R. Abd Rahman, A. B. Salleh, M. Basri, Process Biochem., 2013, 48, 169-175.

[3] Z. Y. Shu, M. J. Duan, J. K. Yang, L. Xu, Y. J. Yan, Biotechnol. Progr., 2009, 25, 409-416.
[4] R. A. Sheldon, Adv. Synth. Catal., 2007, 349, 1289-1307.

[5] S. L. Cao, H. Xu, X. H. Li, W. Y. Lou, M. H. Zong, ACS Sustain. Chem. Eng., 2015, 3, 1589-1599.

[6] N. N. Guan, J. Xu, L. Y. Wang, D. J. Sun, Colloids Surf. A, 2009, 346, 221-228.

[7] Z. P. Yang, C. J. Zhang, J. X. Zhang, W. B. Bai, Biosens. Bioelectron., 2014, 51, 268-273.

[8] J. J. Zhou, P. Wang, C. X. Wang, Y. T. Goh, Z. Fang, P. B. Messersmith, H. W. Duan, ACS Nano, 2015, 9, 6951-6960.

[9] H. Lee, S. M. Dellatore, W. M. Miller, P. B. Messersmith, Science, 2007, 318, 426-430.

[10] J. Ryu, S. H. Ku, H. Lee, C. B. Park, Adv. Funct. Mater., 2010, 20, 2132-2139.

[11] J. J. Zhou, C. X. Wang, P. Wang, P. B. Messersmith, H. W. Duan, Chem. Mater., 2015, 27, 3071-3076.

[12] Y. L. Liu, K. L. Ai, L. H. Lu, Chem. Rev., 2014, 114, 5057-5115.

[13] J. F. Shi, C. Yang, S. H. Zhang, X. L. Wang, Z. Y. Jiang, W. Y. Zhang, X. K. Song, Q. H. Ai, C. Y. Tian, ACS Appl. Mater. Intefaces, 2013, 5, 9991-9997.

[14] K. F. Ni, H. M. Lu, C. X. Wang, K. C. L. Black, D. Z. Wei, Y. H. Ren, P. B. Messersmith, Biotechnol. Bioeng., 2012, 109, 2970-2977.

[15] Y. H. Ren, J. G. Rivera, L. H. He, H. Kulkarni, D. K. Lee, P. B. Messersmith, BMC Biotechnol, 2011, 11, 63.

[16] Y. Shen, A. K. Linderneyer, C. Gonzalez, X. M. Shao, I. Spigelman, R. W. Olsen, J. Liang, J. Neurosci., 2012, 32, 390-401.

[17] W. Li, H. Wu, B. G. Liu, X. D. Hou, D. J. Wan, W. Y. Lou, J. Zhao, J. Biotechnol., 2015, 199, 31-37.

[18] M. M. Bradford, Anal. Biochem., 1976, 72, 248-254.

[19] N. Gupta, P. Rathi, R. Gupta, Anal. Biochem., 2002, 311, 98-99. 


\section{Graphical Abstract}

Chin. J. Catal., 2016, 37: 584-595 doi: 10.1016/S1872-2067(15)61045-2

\section{A magnetic biocatalyst based on mussel-inspired polydopamine and its acylation of dihydromyricetin}

Xiao Deng, Shilin Cao, Ning Li, Hong Wu, Thomas J. Smith *, Minhua Zong, Wenyong Lou*

South China University of Technology, China;

Sheffield Hallam University, UK

The preparation of polydopamine-coated magnetic iron oxide nanoparticles (PD-MNPs), Aspergillus niger lipase (ANL) immobilization on PD-MNPs, and the catalytic activity of ANL@PD-MNPs for dihydromyricetin (DMY) acylation were studied.

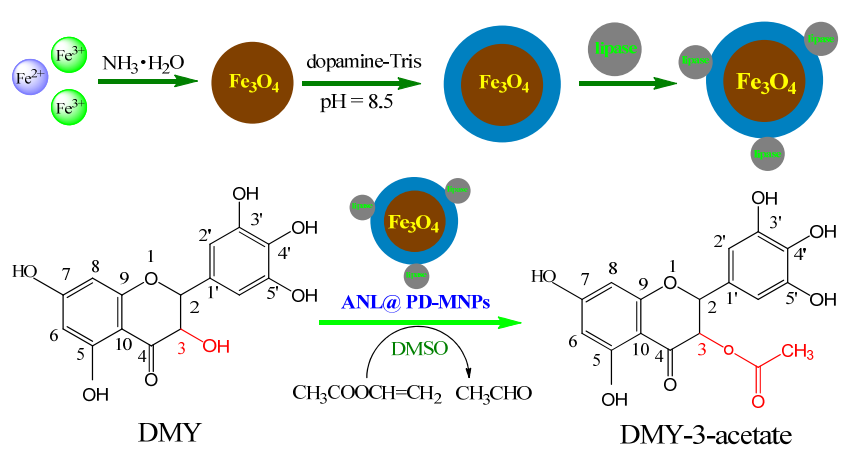

[20] A. Lundin, P. Arner, J. Hellmér, Anal. Biochem., 1989, 177, 125-131.

[21] J. J. Kong, S. N. Yu, Acta Biochim. Biophys. Sin., 2007, 39, 549-559.

[22] S. X. Zhang, Y. Y. Zhang, G. M. Bi, J. S. Liu, Z. G. Wang, Q. Xu, H. Xu, X. Y. Li, J. Hazard. Mater., 2014, 270, 27-34.

[23] C. Y. Li, W. C. Wang, F. J. Xu, L. Q. Zhang, W. T. Yang, J. Membr Sci., 2011, 367, 7-13.

[24] J. Y. Si, H. Yang, Mater. Chem. Phys., 2011, 128, 519-524.

[25] Y. X. Wang, S. H. Wang, H. Y. Niu, Y. L. Ma, T. Zeng, Y. Q. Cai, Z. F. Meng, J. Chromatogr. A, 2013, 1283, 20-26.

[26] H. Qin, C. M. Wang, Q. Q. Dong, L. Zhang, X. Zhang, Z. Y. Ma, Q. R. Han, J. Magn. Magn. Mater., 2015, 381, 120-126.

[27] S. L. Cao, X. H. Li, W. Y. Lou, M. H. Zong, J. Mater. Chem. B, 2014, 2, 5522-5530.

[28] P. Gagnon, P. Toh, J. Lee, J. Chromatogr. A, 2014, 1324, 171-180.

[29] V. Ball, D. D. Frari, V. Toniazzo, D. Ruch, J. Colloid Interface Sci., 2012, 386, 366-372.

[30] F. Xiao, C. Feng, C. G. Jin, X. G. Liu, L. Pan, A. L. Xia, Mater. Lett., 2014, 122, 103-105.

[31] E. Tahmasebi, Y. Yamini, M. Moradi, A. Esrafili, Anal. Chim. Acta, 2013, 770, 68-74.

[32] M. Yakup Arica, H. Soydogan, G. Bayramoglu, Bioproc. Biosyst. Eng., 2010, 33, 227-236.
[33] S. Akgol, Y. Kacar, A. Denizli, M. Y. Arica, Food Chem., 2001, 74, 281-288.

[34] K. M. Polizzi, A. S. Bommarius, J. M. Broering, J. F. Chaparro-Riggers, Curr. Opin. Chem. Biol., 2007, 11, 220-225.

[35] B. A. Kikani, S. Pandey, S. P. Singh, Bioproc. Biosyst. Eng., 2013, 36, 567-577.

[36] D. Kumar, S. Nagar, I. Bhushan, L. Kumar, R. Parshad, V. K. Gupta, J. Mol. Catal. B, 2013, 87, 51-61.

[37] J. Z. Wang, G. H. Zhao, L. Y. Jing, X. M. Peng, Y. F. Li, Biochem. Eng. J., 2015, 95, 75-83.

[38] J. Y. Feng, J. Z. Liu, L. N. Ji, Biochimie, 2008, 90, 1337-1346.

[39] H. Y. Gu, A. M. Yu, H. Y. Chen, J. Electroanal. Chem., 2001, 516, 119-126.

[40] Á. Telbisz, M. Müller, C. Ozvegy-Laczka, L. Homolya, L. Szente, A. Váradi, B. Sarkadi, Biochim. Biophys. Acta-Biomembr, 2007, 1768, 2698-2713.

[41] E. Goormaghtigh, V. Cabiaux, J. M. Ruysschaert, Eur. J. Biochem., 1990, 193, 409-420.

[42] W. K. Surewicz, H. H. Mantsch, D. Chapman, Biochemistry, 1993, 32, 389-394.

[43] M. Mechelke, M. Habeck, Proteins, 2013, 81, 984-993.

[44] A. C. Dong, L. S. Jones, B. A. Kerwin, S. Krishnan, J. F. Carpenter, Anal. Biochem., 2006, 351, 282-289.

\section{基于聚多巴胺的磁性纳米生物催化剂高效催化二氢杨梅素酰化}

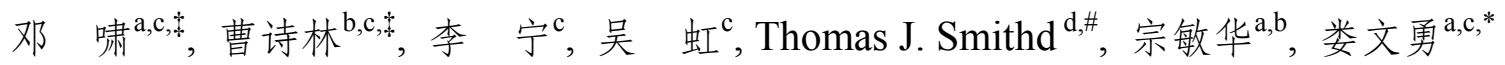

a华南理工大学制浆造纸工程国家重点实验室, 广东广州 510640

b华南理工大学化学与化工学院, 广东广州 510640

c 华南理工大学食品科学与工程学院应用生物催化实验室, 广东广州 510640

谢菲尔德哈勒姆大学生物分子科学研究中心, 谢菲尔德, S1 1WB, 英国

摘要: 脂肪酶是一种三酰基甘油水解酶, 目前广泛用于油脂化学、食品、有机合成和生物医药等领域. 但是, 游离脂肪酶在 有机反应体系中容易失活, 难以从反应体系中回收, 导致其循环利用困难和生产成本增加. 因此, 需要对游离脂肪酶进行 固定化, 提高酶的稳定性和重复使用性, 使其能够大规模用于工业生产.

磁性四氧化三铁纳米粒子(MNPs)具有其超顺磁性和大比表面积等性质, 但MNPs需表面修饰才能进一步应用. 近年来, 仿生矿化法制备的聚多巴胺纳米材料受到人们关注. 在仿生矿化过程中, 单体多巴胺经自聚合作用后形成聚多巴胺, 该反 应活性高, 能对各类有机和无机纳米材料进行表面修饰. 而且, 聚多巴胺表层中的活性基团能与含有氨基和統基的生物大 分子发生迈克尔加成或席夫碱反应, 从而将生物大分子固定在材料表面.

本文利用聚多巴胺表面修饰MNPs, 对所得聚多巴胺表面修饰的四氧化三铁纳米粒子 (PD-MNPs) 进行了结构表征. 结 果表明, PD-MNPs 尺寸在 $14 \mathrm{~nm}$ 左右. 同时, 成功将黑曲需脂肪酶 $(\mathrm{ANL})$ 固定在 PD-MNPs上, 结果显示在 $\mathrm{pH}=8$ 、固定化 
时间为 $12 \mathrm{~h}$ 条件下, 酶负载量为 $138 \mathrm{mg} / \mathrm{g}$, 酶活回收率达到 $83.6 \%$, 而且固定化酶的 $\mathrm{pH}$ 稳定性及热稳定性、储藏稳定性都 优于游离酶. 动力学研究表明, 固定化酶 $K_{\mathrm{m}}$ 值 $(63.2 \mathrm{mmol} / \mathrm{L})$ 低于游离酶 $(74.5 \mathrm{mmol} / \mathrm{L})$, 固定化酶的底物亲和性增强. 进 一步研究了固定化酶和游离酶在乙腈、二甲基亚砜、乙醇和 $\left[\mathrm{HMIm}_{\mathrm{B}} \mathrm{BF}_{4}\right.$ 这四种溶剂中的溶剂耐受性, 结果显示固定化酶的 耐受性均强于游离酶. 采用红外光谱对游离酶和固定化酶二级结构的分析表明, 游离黑曲霉脂肪酶经固定化后, $\alpha$-螺旋和 $\beta$-折叠含量分别增加了 $0.84 \%$ 和 $2.74 \%$, 使得固定化后 $\alpha$-螺旋和 $\beta$-折叠中存在的氢键能够更好地保持酶结构刚性, 避免因 结构改变而引起酶失活, 增强了固定化酶在溶剂中的耐受性.

二氢杨梅素是一种具有类黄酮结构的天然产物, 具有抗氧化、抗菌、抗肿瘤和保护肝脏等作用, 但其脂溶性很差, 很难 透过细胞膜被人体吸收. 本课题组曾首次以乙酸乙烯酯为酰基供体, 采用游离脂肪酶生物催化方法成功将二氢杨梅素酰 化. 本文考察了PD-MNPs固定化脂肪酶在二氢杨梅素酰化反应中的应用. 结果表明, 与游离酶相比, 固定化酶在反应介质 二甲基亚砜中的耐受性更强, 反应 $48 \mathrm{~h}$ 后其催化二氢杨梅素酰化的转化率接近 $80 \%$, 明显好于游离酶 (69\%). 固定化酶催 化二氢杨梅素酰化的最适底物摩尔比、温度和酶量分别为 $10: 1$ (乙酸乙烯酯:二氢杨梅素)、 $45{ }^{\circ} \mathrm{C}$, 和 $40 \mathrm{U}$. 此外, 固定化酶 在外界磁场作用下能迅速从反应混合物中分离, 从而可回收利用, 在重复使用 10 次后, 其活性仍保持在初始活性的 55\% 以上, 具有良好的工业应用前景.

关键词：磁性四氧化三铁; 纳米粒子; 聚多巴胺; 黑曲霉脂肪酶; 二氢杨梅素; 酰化

收稿日期: 2015-11-01. 接受日期: 2016-01-04. 出版日期: 2016-04-05.

*通讯联系人. 电话/传真: (020)22236669; 电子信箱: wylou@scut.edu.cn

\#通讯联系人. 电子信箱: t.j.smith@shu.ac.uk

邤啸与曹诗林为共同第一作者.

基金来源：国家自然科学基金 (21336002；21222606；21376096); 广东省自然科学基金 (S2013020013049); 中央高校基本科研业 务费专项资金 (2015PT002; 2015ZP009); 制浆造纸工程国家重点实验室项目 (2015C04).

本文的英文电子版由Elsevier出版社在ScienceDirect上出版(http://www.sciencedirect.com/science/journal/18722067). 